\title{
The Turkish Society of Colon and Rectal Surgery (TKRCD) Terminology Commission Study Report
}

\section{Türk Kolon ve Rektum Cerrahisi Derneği (TKRCD) Terminoloji Komisyonu Çalışma Raporu}

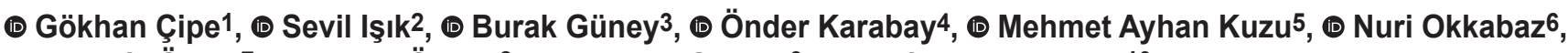 \\ (1) Mustafa Öncel7, (1) Volkan Özben ${ }^{8}$, (1) Neriman Şengül9, (ㄴ Latif Volkan Tümay10 \\ 1'stanbul Atlas University Faculty of Medicine, Department of General Surgery, İstanbul, Turkey \\ 2Medicana International İzmir Hospital, Clinic of General Surgery, İzmir, Turkey \\ ${ }^{3}$ Kilis State Hospital, Clinic of General Surgery, Kilis, Turkey \\ ${ }^{4}$ Yedikule Surp Pırgiç Ermeni Hospital, Clinic of General Surgery, İstanbul, Turkey \\ ${ }^{5}$ Ankara University Faculty of Medicine, Department of General Surgery, Ankara, Turkey \\ ${ }^{6}$ Medipol University Faculty of Medicine, Medipol Mega Hospital, Clinic of Gastroenterology Surgery, İstanbul, Turkey \\ 7İstanbul Medipol University Faculty of Medicine, Department of General Surgery, İstanbul, Turkey \\ ${ }^{8}$ Acıbadem Mehmet Ali Aydınlar University Faculty of Medicine, Department of General Surgery, İstanbul, Turkey \\ ${ }^{9}$ Bolu Abant İzzet Baysal University Faculty of Medicine, Department of General Surgery, Bolu, Turkey \\ ${ }^{10}$ Bursa Hospital Acıbadem Health Group, Clinic of General Surgery, Bursa, Turkey
}

\section{HIIIIII| ABSTRACT}

This study aimed to explain the working order of the Terminology Commission, which was established at the workshop of the Turkish Society of Colon and Rectal Surgery (TKRCD) on February 22, 2020, the criteria and results in the preparation of the terminology report. The commission prepared a work plan to complete in three main steps. The working process continued in a way that the members expressed their opinions with equal rights and the decisions were taken by consensus or by majority vote. The main purpose of the commission study was determined as "determining the terms that need to be explained and agreed in colorectal surgery, and to define them in a way that is compatible with the literature and contributes to daily practice". The first meeting of the commission was held on February 22, 2020, and the report was accepted by the TKRCD Board of Directors on May 25, 2021. A total of 20 meetings were held during this period. In the first step, five headings were determined for writing the terms: Anatomy, symptoms and diagnostic tools, diseases, treatments and complications. There was a consensus that the terms met the following three conditions: 1) the need for explanation and consensus in colorectal surgery, 2) literature support, and 3) use in daily practice. The terms were written in the following format: Terms and synonyms, English equivalents, definition, explanation and bibliography. In the second step, each commissioner wrote an average of $10.8 \pm 4.3$ terms. The distribution of 89 terms in the final report was as follows: Anatomy ( $\mathrm{n}=26,29.2 \%)$, symptoms and diagnostic tools $(n=8,8.9 \%)$, diseases $(n=20,22.4 \%)$, treatments $(n=28,31.4 \%)$, and complications $(n=7,7.8 \%)$. Figures $(n=7)$, all from the archives of the commission members, and figures drawn by a new commission member $(n=53)$ were also added to the report. In the third step, the report was submitted to the TKRCD Management with the approval of the TKRCD President. The preparation process of the Terminology Commission report of TKRCD was presented. The final report is open to changes and expansions with future studies.

Keywords: Workshop report, colorectal surgery, terminology

Terminology Commission Study Report

Gökhan Çipe Prof. MD, - Burak Güney MD, - Sevil Işık Prof. MD, - Önder Karabay Assoc. Prof. - Mehmet Ayhan Kuzu Prof. MD, (President of TKRCD) -

Nuri Okkabaz Assoc. Prof. - Mustafa Öncel Prof. MD, (Head of TKRCD Terminology Commission) -

Volkan Özben Assoc. Prof. (TKRCD Terminology Commission Secretary) - Neriman Şengül Prof. MD, - Volkan Tümay MD, 


\section{||l||l||| ÖZ}

Bu çalışma Türk Kolon ve Rektum Cerrahisi Derneği'nin (TKRCD) 22 Şubat 2020 tarihinde yaptığı çalıştayda kurulan Terminoloji Komisyonu'nun çalışma düzenini, terminoloji raporunun hazırlanmasındaki kriterleri ve sonuçlarını açıklamayı amaçlamaktadır. Komisyon üç ana basamakta tamamlayacak iş planı hazırlamıştır. Çalışma süreci üyelerin eşit haklarla görüş belirttiği ve kararların uzlaşı veya oy çokluğuyla alındığı bir şekilde sürdürülmüştür. Komisyon çalışmasının temel amacı "kolorektal cerrahide açıklanması ve uzlaşı sağlanması gerekli terimlerin belirlenmesi, literatüre uygun ve günlük pratiğe katkı sağlayacak bir şekilde tanımlanması” olarak saptanmıştır. Komisyon ilk toplantısı 22 Şubat 2020 'de yapılmış, rapor ise TKRCD Yönetim Kurulu'nda 25 Mayıs 202l'de kabul edilmiştir. Bu dönemde toplam 20 toplantı yapılmıştır. İlk basamakta terimlerin yazılması için beş adet üst başlık belirlenmiştir: anatomi, semptomlar ve tanı gereçleri, hastalıklar, tedaviler ve komplikasyonlar. Terimlerin şu üç şartı sağlaması konusunda karar birliği oluşmuştur: 1) kolorektal cerrahide açıllanması ve uzlaşı sağlanması gerekliliği, 2) literatür desteği ve 3) günlük pratikte kullanılması. Terimler şu formatta yazılmıştır: terim ve eş anlamlıları, İngilizce karşılıkları, tanım, açıklama ve kaynakça. İkinci basamakta her bir komisyon üyesi ortalama 10,8 4 ,3 terim yazmıştır. Sonuç raporunda yer alan 89 terimin üst başlıklara dağılımı şu şekildedir: anatomi (n=26, \%29,2), semptomlar ve tanı gereçleri $(n=8, \% 8,9)$, hastalıklar $(n=20, \% 22,4)$, tedaviler $(n=28, \% 31,4)$ ve komplikasyonlar $(n=7, \% 7,8)$. Tamamı komisyon üyelerinin arşivlerinden gelen resimler $(n=7)$ ve yeni bir komisyon üyesi tarafından çizilen şekiller de $(n=53)$ rapora eklenmiştir. Üçüncü basamakta rapor TKRCD Başkanının onayıyla TKRCD Yönetimi'ne sunulmuştur. TKRCD’nin Terminoloji Komisyonu raporunun hazırlık süreci sunulmuştur. Sonuç raporu ileride yapılacak çalışmalarla değişiklik ve genişletmelere açıktır.

Anahtar Kelimeler: Çalıştay raporu, kolorektal cerrahi, terminoloji

\section{Introduction}

Naming and defining are the first step for human beings to embody the concept of learning. On the other hand, learning the human body and creating a common language in medical terminology have become an integral part of health education, research, scientific publications, and perhaps

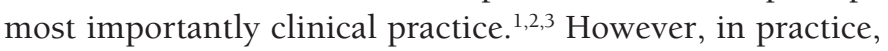
besides the anatomical structures, the presence of different definitions of patients' presentation symptoms, diseases and treatments, and even complications are noteworthy. It is also striking that the use of standardized definitions and agreed terms in the literature is not as much foregrounded as other elements, for example statistical significance, during the writing of the studies. ${ }^{1}$

The importance of making the definitions and terms used in daily medical practice in a way that is understood and agreed by everyone is very obvious. However, even in some frequently used terms, such a common language is sometimes not established. For example, it remains unclear how to name the examination of the anal canal and rectum, which is the simplest application of colorectal practice in many surgical clinics. Whether the use of the term "rectal touch" for digital rectal examination is a correct practice is still a matter of debate. ${ }^{4}$ Although the lack of a common language is seen as insignificant because it does not affect the treatment process of the patient in particular, some other disagreements and uncertainties have the potential to cause significant clinical problems. For example, in an international consensus meeting with specialists specialized in colorectal surgery, a consensus could not be reached even on how far the rectum extends from the anal canal. Moreover, although 10 different definitions of the rectum were presented in this consensus study, $12 \%$ of the experts did not find any of them appropriate and made their own unique definitions. ${ }^{5}$ The definition of where the rectum is, is the first step in the management of many diseases in this region. Preoperative neoadjuvant radiotherapy is recommended for locally advanced cancers, if the disease is located in the middle or lower rectum.

For this reason, The Turkish Society of Colon and Rectal Surgery (TKRCD) decided to make a terminology study to be a reference for its members and the Turkish colorectal community, and shared it with the members of the association in the workshop held on February 22, 2020. At this meeting, such a need was underlined and the study was supported. On the other hand, it may be a very wellintentioned guess that the terms prepared by the commission are accepted by everyone. The main reason for this is that various teams in our country have developed a common language among themselves for many years. The consensus report of the Commission and the proposed terms will likely be criticized in this respect. For this reason, it is a necessity to share the technical details of the process from the election of the commission to the submission of the report to the TKRCD management and the methodology of writing the terms in detail. This study aims to share the progress stages of this process in detail.

\section{Materials and Methods}

In the workshop held by TKRCD on February 22, 2020, a consensus was reached on the establishment of a commission to work on terminology. Eight surgeons who would also take part in the first plan were announced. The surgeons in the commission were determined before the workshop by the board of directors of the society among the surgeons who were members of TKRCD and who were involved in scientific studies organized within the society for many years. Other participants in the workshop were also free to join the commission and take part in the next process. The 
works were carried out under the chairmanship of a member of the board of directors in order to ensure coordination with the board of directors. Members' participation in the commission was on a voluntary basis, but the members of the commission were obliged to attend all meetings except for force majeure. The working process continued in a way that the members expressed their opinions with equal rights and the decisions were taken by consensus or by majority vote. The prepared report was presented to the head of TKRCD at various stages and his suggestions were received. The main purpose of the commission study was determined as "determining the terms that need to be explained and agreed in colorectal surgery and defined in a way that is appropriate to the literature and contributes to daily practice". The commission held its first meeting on the day of the workshop and determined its secretary. He laid out his work plan at the first meetings (Table 1). The meetings were planned to be held face to face. Before each meeting, it was foreseen that the members should study the determined topics and convey their suggestions to the secretary, that the suggestions were combined by the secretary and delivered to all members for preparation before the meeting. Members who were assigned the task of writing the terms during the preparation phase were released to exchange views with each other or with other surgeons outside the commission during the preparation phase. In addition, it was stipulated

Table 1. The work plan of the terminology commission

Determining the categories (headings) of the terms

Determining criteria for inclusion of terms in the report

Step 1. Preliminary study

Determining the spelling format of terms

Determination of terms

Determining who will write the terms

Writing the determined terms by the members

Revision of writings: review or cancellation (if needed) of term explanations by the commission and opening new titles by the commission

Completion of explanations and references of written terms

Presentation of the preliminary report to the President of Turkish Society of Colon and Rectal Surgery

Step 3. Consensus and finalization of the report that the existing literature should be searched and a bibliography should be found in the prepared texts. Before the preparation report of the commission was given its final form, it was planned to receive suggestions by conveying it to the head of TKRCD.

\section{Results}

The commission was determined by the TKRCD Board of Directors among physicians who were members of TKRCD and experienced in colorectal surgery. The first meeting was held on February 22, 2020, the day of the workshop, and the report was accepted by the TKRCD Board of Directors on May 25, 2021. The working period of the commission lasted approximately 15 months. Although the commission meetings to be held in line with the work program were planned face-to-face, the meetings were mostly held over the internet, as the process overlapped with the COVID-19 pandemic period. Despite the pandemic process, face-toface meetings were also held intermittently due to necessity. During this period, a total of 20 meetings were held, 18 of which were online and 2 of them face-to-face, with a duration varying between 1.5 and 6 hours. The preparation process of the report was progressed in accordance with the work plan prepared in the first meetings.

\section{Step 1: Preliminary work}

In order to determine the terms planned to be written, the topics were categorized and five headings were determined: Anatomy, symptoms and diagnostic tools, diseases, treatments and complications.

For the terms to be written, in accordance with the purpose of the commission's establishment, a consensus was reached on the following three conditions for the terms to be included in the study: 1) the need for explanation and consensus in colorectal surgery, 2) the ability to provide literature support, and 3) the use in daily practice.

The following format was followed in the writing of the terms: The term (in the first place the term deemed appropriate by the commission) and its synonyms (or other terms deemed appropriate to be explained under the same title), the English equivalent or equivalents, definition, explanation and bibliography. During the writing of the terms, it was decided not to pursue a persistent Turkish translation purpose and to accept foreign words as they were if they were generally known.

In the next meetings, the recommendations of the commission members were combined and discussed, with a total of 87 terms under the headings of anatomy $(n=27)$, symptoms and diagnostic tools $(n=8)$, diseases $(n=24)$, treatments $(n=20)$ and complications $(n=8)$ were deemed worthy of inclusion in the report. 


\section{Step 2: Writing the terms and developing the report}

At this stage, it was decided by whom which terms would be written with the voluntary participation of the commission members. Each commission member wrote an average of (standard deviation) $10.8( \pm 4.3)$ terms, but the members also received opinions from other TKRCD members who were not members of the commission, if they deemed necessary. During the writing, literature support was deemed absolutely necessary and the publications frequently cited in the meetings were re-checked.

The control of the writing format and content of the terms written in their meetings was discussed by the members of the commission, and a consensus was tried to be reached, and in cases where this could not be achieved, a decision was made by voting. The meanings of the previously determined terms were written by determining their synonyms. Also, similar terms were grouped together. With these regulations, it was aimed that the researcher, who would question a term in the final report in the future, could reach similar terms and have an idea about their differences. Again in the commission meetings, 9 (10.3\%) terms were deemed unnecessary and canceled, and 8 (9.2\%) terms were combined with similar titles or among themselves. In addition, sub-terms were determined for some terms under the same category and these terms were defined separately. In the interim evaluations, it was decided to add new terms $(n=7)$ upon the recommendation of the President of TKRCD. As a result, their definitions were completed and the distribution of the 89 terms in the final report was as follows: Anatomy $(\mathrm{n}=26,29.2 \%)$, symptoms and diagnostic tools $(\mathrm{n}=8,8.9 \%)$, diseases $(n=20,22 \%, 4)$, treatments $(n=28,31.4 \%)$, and complications ( $\mathrm{n}=7,7.8 \%)$.

Again, in this stage, it was decided to add pictures and figures to the texts with the suggestion of the President of TKRCD. For this purpose, a TKRCD member, a general surgery specialist (BG), who had experience in medical drawing and had been involved in similar studies before, was unanimously added to the commission. In this direction, pictures $(n=7)$ from the archives of the commission members and the figures drawn by the new commission member $(n=53)$ were also studied and added to the report in the subsequent meetings. An example drawing is presented in Figure 1. Many corrections were made for each picture and figure with the suggestions of the commission members.

\section{Step 3: Consensus and finalization of the report}

In the last step, text explanations, pictures and figures were combined, and the typo and spelling were checked once again. Following this, the report was made into a file by the secretary of the commission and presented to the management of TKRCD through the approval of the President of TKRCD. These terms are planned to be included in the official website of TKRCD.

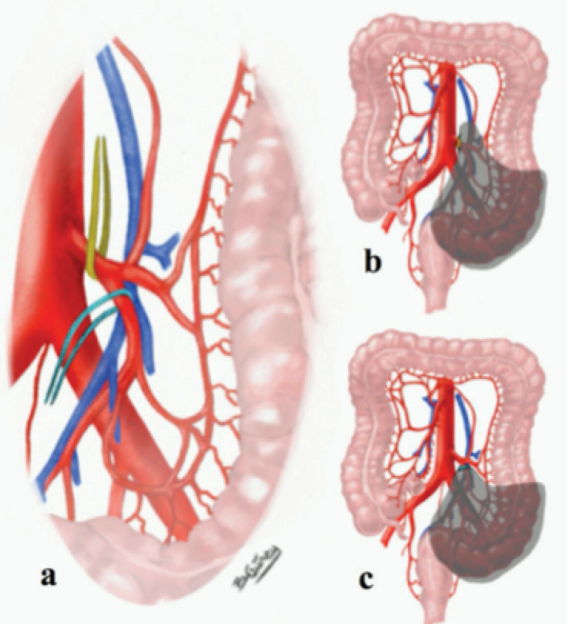

Figure 1. A sample drawing prepared by the terminology commission. This drawing shows high and low ligation and resection margins with threads of different colors

\section{Discussion}

In order for the human brain to embody a concept, it is necessary to give it a name in the first step. Differences in definition in medicine, especially in surgery, pose an important problem for researchers, clinicians, and patients. ${ }^{5}$ For this purpose, TKRCD decided to prepare a terminology report for the use of physicians practicing in the field of colorectal surgery. This study aimed to explain the working order of the commission established for this purpose, the criteria and results it set forth to prepare the terminology report.

The process of preparing terminology reports involves some difficulties. Among these, it is to choose the people who will take part in the commission who will make the definition. At this stage, the initiative of societies to form working groups is a solution that is both fast and suitable for the flow of life. In the literature, it is frequently seen that various gynecology and anatomy societies have formed commissions or working groups to define anatomical structures. ${ }^{1,6,7}$ In this study, the members of the commission were selected from among its own members by the TKRCD Board of Directors, who were dealing with colorectal surgery for many years. In addition, it was underlined that all members who wanted to take part in the work of the commission during and after the workshop held on February 22, 2020 could take part in the work of the commission. Similarly, the commission was expanded in case of need. For example, the commission decided to expand on the decision to include pictures in the report and invited new members. In addition, the commission did not hesitate to get suggestions by contacting the opinions of people outside the commission (for example, the President of TKRCD). Some descriptive studies achieved consensus on terminology through questionnaires. ${ }^{1}$ However, such an application may not have literature support. Moreover, there 
is a potential for criticism from those who disagree with the survey's final decision or those who have not participated. Commissions are more often accepted as they conduct literature searches and create environments for discussion on each term.

Which terms to include in the report is another difficult topic. Regardless of the number of items in the final report, it can be predicted that why some terms are included in the scope of this study or, on the contrary, why some terms are excluded from the report will be an important point of criticism. This issue is most likely one of the serious difficulties in preparing such reports, as this point is very subjective and individual differences are commonplace. For example, a surgeon who has a lot of practice in cancer may hope that even more detailed terms on this subject will be included in the report, while another surgeon who practices less on this subject may want simpler terms to be included in the report. For this reason, the commission found it appropriate to stay within reasonable limits on this issue and determined that it should be used more frequently in "daily practice" at the beginning as the main criterion for inclusion in the report.

Also it is impossible that the items written and the terms suggested are accepted, liked and approved by everyone. This is especially true when a concept is expressed in many terms. In such a case, the terms are understood or named differently by various teams and centers. For this reason, this is the area where consensus commissions have the most difficulty. In a multicenter study aiming to explain where the rectum was anatomically, only $36 \%$ of all participants agreed on the concept of "rectum" in the final report, while the others did not accept the result. However, 92.4\% of those who voted in the same study emphasized that it was important to make this definition. ${ }^{5}$ It is possible to see similar differences in other terms. For example, there is still no consensus on the definition of anastomotic leak. ${ }^{8}$ One systematic review states that there are 29 different definitions for lower gastrointestinal tract anastomotic leaks. ${ }^{9}$ In a situation where even consensus texts find it difficult to come up with a single definition for terms, it would be too optimistic to predict universal acceptance of the definitions presented in the report. ${ }^{5}$ The commission mentioned in this study consisted of physicians who were dealing with colorectal surgery for years. The final report, which included the terms studied, was prepared as a result of many meetings held over a long period of 15 months. Literature support was sought in the writing of all terms. Despite all these well-intentioned efforts, the written terms are not unchangeable texts. In line with future criticisms, it is possible to change and improve the final report by reviewing it in the future. Especially since the language has a living, changing and dynamic structure, it can be predicted that this report will be a step towards a better definition of these terms in the future and new definitions will be made that are less affected by the limitations listed. The important point is to assume that the presented text is a well-intentioned final report prepared by TKRCD and to take part in the effort to advance it.

As a result, this study explains the working order of the TKRCD terminology commission, the criteria it has set for preparing the terminology report, and its results. It may be appropriate to evaluate the report on the official website of TKRCD with this information. It is possible to develop the report in the future.

Peer-review: Internally peer reviewed.

\section{Authorship Contributions}

Concept: G.Ç., S.I., B.G., Ö.K., M.A.K., N.O., M.Ö., V.Ö., N.S.., L.V.T., Design: G.Ç., S.I., B.G., Ö.K., M.A.K., N.O., M.Ö., V.Ö., N.Ş., L.V.T., Data Collection or Processing: M.Ö., V.Ö., Analysis or Interpretation: G.Ç., S.I., B.G., Ö.K., M.A.K., N.O., M.Ö., V.Ö., N.Ş., M.Ö., V.Ö., Literature Search: S.I., B.G., Ö.K., M.Ö., V.Ö., L.V.T., Writing: M.Ö., V.Ö.

Conflict of Interest: No conflict of interest was declared by the authors.

Financial Disclosure: The authors declared that this study received no financial support.

\section{References}

1. Balgobin S, Jeppson PC, Wheeler T 2nd, Hill AJ, Mishra K, Mazloomdoost D, Dunivan GC, Anand M, Mama ST, Bochenska K, Lewicky-Gaupp C, Balk EM, DeLancey J, Corton MM; Society of Gynecologic Surgeons Pelvic Anatomy Group. Standardized terminology of apical structures in female pelvis based on a structured medical literatüre review. Am J Obstet Gynecol 2020;3:204-218

2. Greathouse DG, Halle JS, Dalley AF. Terminologia Anatomica: revised anatomical terminology. J Orthop Sports Phys Ther 2004;34:363-368.

3. Hirsch BE. Does the terminologia anatomica really matter? Clin Anat. 2011;24:503-504

4. Yakıncı C, Akın K, Almıs H. Tıp Terim Biliminde bildiklerimizden bilmediklerimize ulaşma. Çocuk Sağlığı ve Hastalıkları Dergisi 2013;56:97100

5. D'Souza N, Babberich MPM, d'Hoore A, Tiret E, Xynos E, Beets-Tan RGH ve ark. Definition of the rectum. An international, expert-based delphi consensus. Ann Surg 2019;270:955-959.

6. American Association of Clinical Anatomists, Educational Affairs Committee. The clinical anatomy of several invasive procedures. Clin Anat 1999; 12:43-54

7. Rahbari NN, Weitz J, Hohenberger W, Heald RJ, Moran B, Ulrich A, Holm T, Wong WD, Tiret E, Moriya Y, Laurberg S, den Dulk M, van de Velde C, Buchler MW, Definition and grading of anastomotic leakage following anterior resecton of rectum: a proposal bu the International Study Group of Rectal Cancer. Surgery 2010;147:339-351.

8. van Rooijen SJ, Jongen AC, Wu ZQ, Ji JF, Slooter GD, Roumen RM, Bouvy ND. World J Gastroenterol 2017;7:6172-6180.

9. Bruce J, Krukowski H, Al-Khairy G, Russell EM, Park KGM. Systemic review of the defintion and measurement of anastomotic leak after gastrointestinal surgery. Br J Surg 2001;88:1157-1168. 